\title{
Beetles (Coleoptera) new for the fauna of the Białowieża Forest including a species new for Poland
}

\author{
Radosław Plewa, Tomasz Jaworski, Grzegorz Tarwacki, Krzysztof Sućko, Szymon \\ Konwerski, Roman Królik, Andrzej Lasoń, Andrzej Melke, Marek Przewoźny, Rafał Ruta, \\ Henryk Szołtys \& Jacek Hilszczański
}

Plewa, R., Jaworski, T., Tarwacki, G., Sućko, K., Konwerski, S., Królik, R., Lasoń, A., Melke, A., Przewoźny, M., Ruta, R., Szołtys, H. \& Hilszczański, J. 2019: Beetles (Coleoptera) new for the fauna of the Białowieża Forest including a species new for Poland. — Entomol. Fennica 30: 114-125. https://doi.org/ $10.33338 /$ ef. 84086

The paper presents new data on the occurrence of 69 beetle species collected in 2017 in the Białowieża Forest, NE Poland. The list contains representatives of 27 families: Anthribidae, Bostrichidae, Ciidae, Cleridae, Coccinellidae, Corylophidae, Cryptophagidae, Curculionidae, Dasytidae, Elateridae, Endomychidae, Eucnemidae, Histeridae, Laemophloeidae, Latridiidae, Leiodidae, Lycidae, Melandryidae, Mycetophagidae, Ptinidae, Ripiphoridae, Salpingidae, Staphylinidae, Tenebrionidae, Tetratomidae, Throscidae, and Zopheridae. The majority of the species represents saproxylic, i.e. dead wood-dependent, beetles. Biology and distribution of some rarely recorded species are briefly discussed. All species are reported for the first time from the Białowieża Forest and, furthermore, Corticaria crenicollis Mannerheim, 1844 (Latridiidae) is new for the fauna of Poland.

R. Plewa, T. Jaworski, G. Tarwacki \& J. Hilszczański, Department of Forest Protection, Forest Research Institute, Sękocin Stary, Braci Leśnej 3, 05-090 Raszyn, Poland; E-mails: r.plewa@ibles.waw.pl, t.jaworski@ibles.waw.pl, g.tarwacki@ibles.waw.pl,j.hilszczanski@ibles.waw.pl

K. Sućko, Department of Natural Forests, Forest Research Institute, Białowieża, ParkDyrekcyjny6,Białowieża 17-230,Poland;E-mail:k.sucko@ibles.waw.pl

S. Konwerski, Natural History Collections, Faculty of Biology, Adam Mickiewicz University,Umultowska 89,61-614 Poznań; E-mail: szymkonw@amu.edu.pl

R. Królik, Ligota Zamecka 56A, 46-200 Kluczbork; E-mail: agrilus @poczta.onet.pl

A. Lasoń,Wiejska 4B/85, 15-352 Biatystok; E-mail: haptos@interia.pl

A.Melke,Św.Stanistawa 11/5,62-800Kalisz;E-mail: kusakowaty@gmail.com

M. Przewoźny, Department of Systematic Zoology, Faculty of Biology, Adam Mickiewicz University, Umultowska 89, 61-614 Poznań; E-mail: hygrotus @amu.edu.pl

R. Ruta, Department of Biodiversity and Evolutionary Taxonomy, University of Wrocław, Przybyszewskiego 65, 51-148 Wrocław; E-mail: rafal.ruta@uwr. edu.pl

H. Szołtys, Park 9, 42-690 Brynek; E-mail: henryk.szoltys@wp.pl

Received 22 June 2018, accepted 19 September 2018 


\section{Introduction}

Research on the fauna of beetles of the Polish part of the Białowieża Forest began in the first half of the $20^{\text {th }}$ century and focused mainly on bark beetles (Curculionidae, Scolytinae), and later also on longhorn beetles (Cerambycidae) (Karpiński 1933, 1949). A number of studies were later carried out by Burakowski (e.g. 1962a, 1962b, 1975, 1988), which has contributed significantly to the knowledge about the bionomics and descriptions of the developmental stages of many species. In subsequent years, the Białowieża Forest was still an important object of coleopterological research, as evidenced by many publications documenting number of species new for this area, and also for Poland. Faunistic exploration of the Białowieża Forest was intensified in 1980's and at the beginning of 1990's. As a result, over 380 species of beetles were newly recorded from the Białowieża Forest by Kubisz and Szwałko (1991) and Borowiec et al. (1992). Moreover, several long-term studies on beetles of the Białowieża Forest were initiated in 1980's (Gutowski \& Kubisz 1995, Gutowski 2004). The results of these papers were later summarized in the Catalogue of the fauna of Białowieża Primeval Forest (Gutowski \& Jaroszewicz 2001), and thus far, it is the only forest area in Poland with such a comprehensive study. In a consequence, the number of Coleoptera of this area was estimated as approximately 3,200 species (Gutowski \& Jaroszewicz 2004).

Further research in the Białowieża Forest has focused on the zooindication-based valuation of forests based on the species composition and abundance of epigeic (i.e. living on the soil surface) and saproxylic (i.e. associated with dead wood and wood-decaying fungi) beetles (Szujecki 2001, 2006, 2017). The latest works were based on the analysis of saproxylic beetle assemblages in the tree tops of mature oak stands of this area (Plewa et al. 2014, 2017).

Although the area of the Białowieża Forest has been quite well investigated in terms of beetle fauna, a number of unlisted species should be expected to occur there. This is mainly due to the spatial extent and habitat diversity of the area, its inaccessibility, and the continuity of natural processes. Our study provides data on the occurrence of beetle species new for the fauna of the Białowieża Forest and Poland.

\section{Materials and methods}

All beetles were collected using 12-funnel traps (purple, polytetrafluoroethylene (PTFE)-covered) equipped with a collection chamber halffilled with ethylene glycol to preserve captured insects (Fig. 1). A total of 335 traps were dis-

Fig. 1. Purple multiple funnel trap exposed in one of the sampling sites in the Białowieża Forest in 2017.

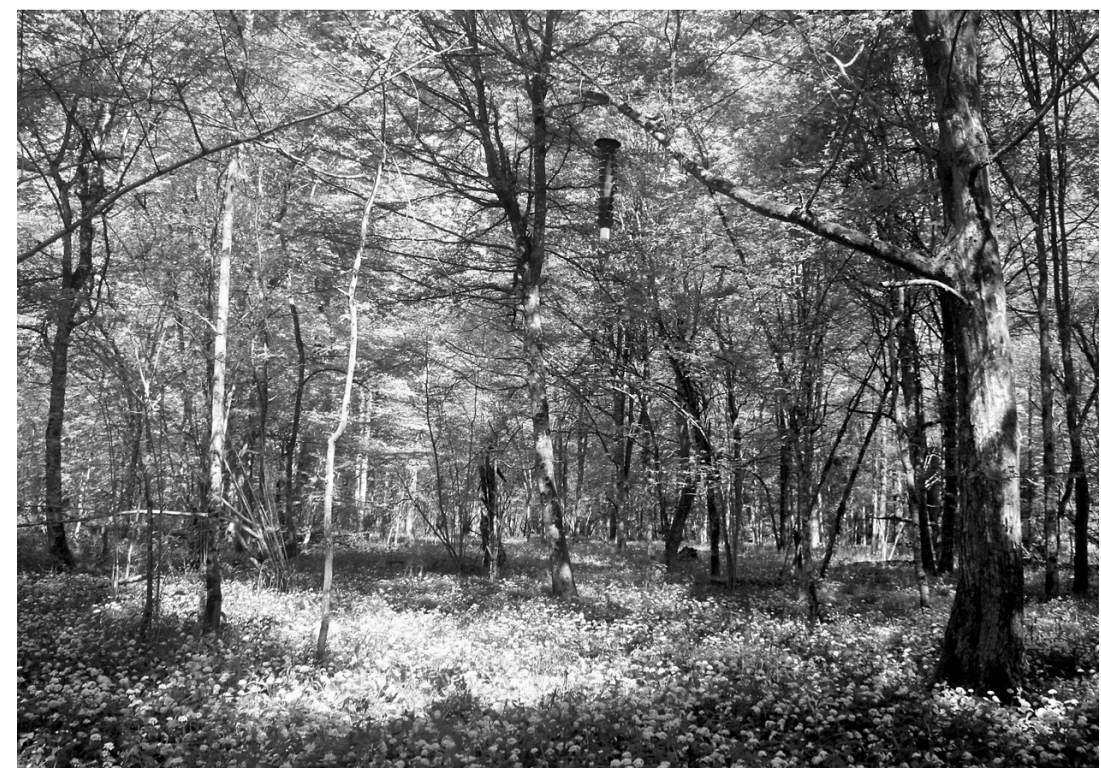




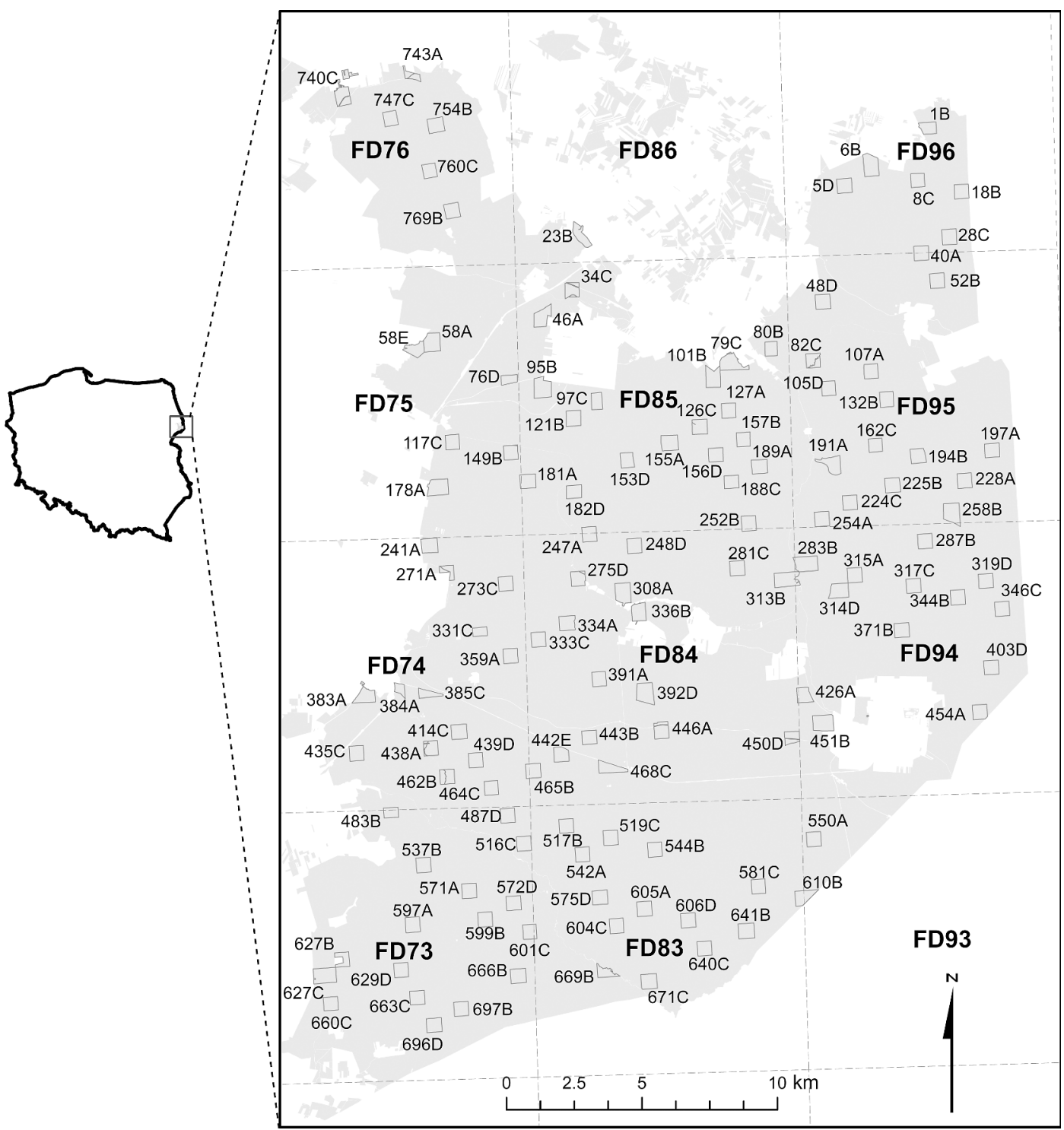

Fig. 2. Study sites within UTM squares.

played from mid-May to mid-September 2017 in selected sites of the study area in the Białowieża Forest (Fig. 2). The traps were hanged on the lower braches of trees at a height of 3-5 $\mathrm{m}$ above the ground level, and were emptied every $1-1.5$ month.

The beetles were identified by all authors. Determinations of some taxa were further confirmed by RP (Latridiidae), SK (Leiodidae), RK (Ciidae), AM (Staphylinidae), MP (Eucnemidae), RR (Corylophidae), AL and HS (Elateridae). Identification of several species of Latri- diidae was confirmed also by W. H. Rücker. Taxonomic nomenclature follows Catalogue of $\mathrm{Pa}$ laearctic Coleoptera by Löbl and Smetana (2007, 2008, 2011) with further amendments by Löbl and Löbl (2015).

The list of beetle families and species is presented in alphabetical order. The locality names, i.e. Białowieża, Browsk, Hajnówka, refer to the areas administered by the three local forest districts (i.e. Białowieża Forest District, Browsk Forest District, and Hajnówka Forest District, respectively), while BNP refers to the area of 
Białowieża National Park. Symbols in square brackets are designations of the forest territorial units (so-called "subcompartments"), according to the territorial division of the Białowieża Forest. To avoid unnecessary duplication of data in the systematic part of the paper, the location of each subcompartment within the particular UTM (Universal Transverse Mercator) square is shown in Fig. 2. Numbers of collected individuals of beetles are provided, followed by the information about trapping duration (Arabic and Roman numerals indicate days and months of 2017, respectively).

\section{Annotated list of new Coleoptera species of the Białowieża Forest}

\section{Anthribidae}

Gonotropis dorsalis (Gyllenhal, 1813)

Browsk: [6B] 1 ex. 25.V.-19.VI.

Phaeochrotes pudens (Gyllenhal, 1833)

Białowieża: [454A] 1 ex. 4.VIII.-7.IX., [281C] 1 ex. 24.VI.-7.VIII., [336B] 1 ex. 7.VIII.-12.IX.

Browsk: [82C] 3 exx. 19.VI.-4.VIII., [58A] 1 ex. 22.VI.-7.VIII., [58E] 7 exx. 22.VI.-7.VIII., [58E] 1 ex. 7.VIII.-12.IX.

Hajnówka: [516C] 1 ex. 6.VIII.-13.IX., [629D] 5 exx. 21.VI.-4.VI., [660C] 3 exx. 21.VI.-4.VIII., [660C] 4 exx. 4.VIII.-11.IX.

Pseudeuparius sepicola (Fabricius, 1792)

Hajnówka: [241A] 1 ex. 25.VI.-8.VIII.

\section{Bostrichidae}

Lyctus pubescens Panzer, 1792

Białowieża: [606D] 1 ex. 19.V.-20.VI.

Rhyzopertha dominica (Fabricius, 1792)

Browsk: [58E] 1 ex. 22.VI.-7.VIII.

Remarks: A cosmopolitan species, which has been introduced to many countries from the IndoMalayan region. In the tropics, it develops on the branches of various tree species. In the temperate zone, the larvae have adapted to feeding in cereal grains and in stored food products (Burakowski et al. 1986, Borowski \& Węgrzynowicz 2012). The Białowieża Forest is the second locality in Poland, in which this species has been found in natu- ral conditions, i.e. outside of the synanthropic environments (Klejdysz \& Nawrot 2010).

\section{Ciidae}

Orthocis linearis (Sahlberg J. R., 1901)

Browsk: [40A] 1 ex. 19.VI.-3.VIII., [157B] 1 ex. 24.V.-20.VI.

Hajnówka: [334A] 1 ex. 25.VI.-9.VIII., [572D] 1 ex. 22.V.-20.VI.

Remarks: Currently, the species has been recorded from the Wielkopolsko-Kujawska Lowland and the Małopolska Upland (Plewa \& Królik 2013). At the turn of the $19^{\text {th }}$ and $20^{\text {th }}$ centuries, it was reported also from the Masovian Lowland and the Eastern Beskidy Mountains (Królik 2002, 2008).

\section{Cleridae}

Korynetes caeruleus (De Geer, 1775)

Browsk: [760C] 1 ex. 8.VIII.-13.IX., [121B] 1 ex. 21.VI.-6.VIII., [181A] 1 ex. 21.VI.-6.VIII., [97C] 1 ex. 23.V.-20.VI.

Hajnówka: [435C] 1 ex. 19.V.-24.VI.

\section{Coccinellidae}

Nephus quadrimaculatus (Herbst, 1783)

Białowieża: [450D] 1 ex. 20.V.-22.VI.

BPN: [317C] 1 ex. 24.V.-21.VI., [371B] 1 ex. 20.V.-23.VI.

Oenopia impustulata (Linnaeus, 1767)

Browsk: [740C] 2 exx. 17.V.-23.VI., [34C] 1 ex. 21.VI.-7.VIII.

\section{Corylophidae}

Arthrolips nana (Mulsant et Rey, 1861)

Białowieża: [581C] 1 ex. 18.V.-20.VI.

Browsk: [157B] 1 ex. 24.V.-20.VI.

Hajnówka: [384A] 3 exx. 24.VI.-7.VIII., [438A] 1 ex. 18.V.-24.VI., [438A] 1 ex. 24.VI.7.VIII.

\section{Cryptophagidae}

Antherophagus similis Curtis, 1835

Browsk: [8C] 1 ex. 19.VI.-3.VIII.

Ephistemus reitteri Casey, 1900

Browsk: [126C] 1 ex. 24.V.-20.VI.

Hajnówka: [438A] 2 exx. 24.VI.-7.VIII.

Ootypus globosus (Waltl, 1838)

Browsk: [156D] 1 ex. 6.VIII.-9.IX. 


\section{Curculionidae}

Xyleborus dryographus (Ratzeburg, 1837)

Białowieża: [544B] 1 ex. 22.VI.-8.VIII.

Hajnówka: [359A] 1 ex. 9.VIII.-14.IX., [438A] 2 exx. 18.V.-24.VI.

\section{Dasytidae}

Dasytes fusculus (Illiger, 1801)

BNP: [105D] 1 ex. 22.VI.-9.VIII.

Trichoceble floralis (Olivier, 1790)

Białowieża: [392D] 1 ex. 24.VI.-7.VIII.

BNP: [344B] 1 ex. 22.V.-20.VI.

Browsk: [82C] 1 ex. 19.VI.-4.VIII., [76D] 1 ex. 21.VI.-7.VIII.

Hajnówka: [414C] 1 ex. 18.V.-24.VI., [537B] 1 ex. 19.V.-23.VI.

\section{Elateridae}

Cidnopus pilosus (Leske, 1785)

Browsk: [769B] 1 ex. 17.V.-23.VI.

Podeonius acuticornis (Germar, 1824)

Białowieża: [308A] 1 ex. 25.V.-24.VI.

BNP: [315A] 1 ex. 20.V.-25.VI.

Remarks: So far, the species has been known only from Rogalin on the Warta River near Poznań (Buchholz 1987). This species is listed in the Polish Red Data Book of Animals as well as in the IUCN Red List of Threatened Species (category $\mathrm{CR}$ - critically endangered) (Pawłowski et al. 2002, Buchholz 2004a).

Larval development takes place in the hollows of oaks or beeches. Larvae are predatory and feed on small larvae of other insects, e.g. beetles from the genus Cossonus Schellenberg J. R., 1798 or on larvae of mycetophilid flies. Larval development lasts at least three years (Buchholz 1987, 2004a).

Sericus subaeneus (Redtenbacher W., 1842)

Hajnówka: [462B] 1 ex. 18.V.-24.VI.

Remarks: Thus far, the species has been recorded only from Southern Poland. A summary of the literature of this species was presented by Tarnawski et al. (2007). The species is listed in the Polish Red Data Book of Animals and in the IUCN Red List of Threatened Species (category VU - vulnerable species) (Pawłowski et al. 2002, Buchholz 2004b).

The species inhabits moist soils that are rich in organic matter, preferably in cool and shaded sites. Larvae live in soil under moss and herbaceous plants, feeding on their underground parts. The development of the species takes 3-4 years (Burakowski 2002).

\section{Endomychidae}

Symbiotes gibberosus (Lucas P. H., 1846)

Browsk: [48D] 1 ex. 25.V.-19.VI.

Hajnówka: [597A] 1 ex. 19.V.-23.VI.

Remarks: The species has been recorded very rarely. Nowadays known from the Wielkopolsko-Kujawska Lowland (Jałoszyński \& Konwerski 2005, Przewoźny 2013), Lower and Upper Silesia (Szołtys \& Grzywocz 2014).

\section{Eucnemidae}

Isorhipis melasoides (Laporte, 1835)

Białowieża: [581C] 7 exx. 18.V.-20.VI., [581C] 1 ex. 20.VI.-4.VIII., [610B] 1 ex. 18.V.20.VI., [610B] 1 ex. 20.VI.-4.VIII., [610B] 1 ex. 4.VIII.-8.IX., [605A] 1 ex. 20.VI.-8.VIII., [606D] 1 ex. 20.VI.-8.VIII.

BNP: [224C] 1 ex. 23.V.-23.VI., [315A] 1 ex. 20.V.-25.VI., [315A] 2 exx. 25.VI.-8.VIII., [189A] 1 ex. 24.V.-24.VI., [132B] 1 ex. 25.V.22.VI., [162C] 2 exx. 24.V.-22.VI., [162C] 1 ex. 22.VI.-8.VIII., [191A] 2 exx. 24.V.-23.VI., [258B] 7 exx. 24.V.-22.VI.

Browsk: [5D] 1 ex. 25.V.-19.VI., [48D] 2 exx. 19.VI.-4.VIII., [82C] 2 exx. 25.V.-19.VI., [769B] 1 ex. 8.VIII.-13.IX., [117C] 2 exx. 22.V.-21.VI., [76D] 1 ex. 21.VI.-7.VIII., [156D] 1 ex. 24.V.-20.VI.

Hajnówka: [334A] 1 ex. 22.V.-25.VI., [384A] 2 exx. 19.V.-24.VI., [438A] 1 ex. 24.VI.-7.VIII., [462B] 2 exx. 18.V.-24.VI., [414C] 1 ex. 18.V.-24.VI., [439D] 1 ex. 18.V.24.VI., [519C] 1 ex. 18.V.-22.VI., [542A] 1 ex. 17.V.-22.VI., [604C] 1 ex. 17.V.-20.VI., [483B] 1 ex. 23.VI.-5.VIII., [537B] 1 ex. 19.V.-23.VI., [571A] 6 exx. 22.V.-23.VI., [571A] 1 ex. 23.VI.-5.VIII., [601C] 1 ex. 18.V.-20.VI., [599B] 2 exx. 18.V.-20.VI.

Remarks: The species is rare and sporadically encountered. So far, it has been recorded from six regions in Poland (Hilszczański et al. 2015).

The larval development takes place in moist, yet still undecomposed hardwood of broadleaved trees (Burakowski 1991, Buchholz 2008). The 
authors (RP and TJ) observed infested hardwood of standing dead beech (Fagus sylvatica L.) infested with tinder fungus (Fomes fomentarius L. (Fr.)) in Wielkopolsko-Kujawska Lowland (vicinity of Koźminiec village, 17.II.2016).

\section{Histeridae}

Carcinops pumilio (Erichson, 1834)

Browsk: [743A] 1 ex. 23.VI.-8.VIII.

\section{Laemophloeidae}

Cryptolestes weisei (Reitter, 1880)

Hajnówka: [697B] 1 ex. 17.V.-21.VI.

Laemophloeus monilis (Fabricius, 1787)

Białowieża: [248D] 1 ex. 25.V.-24.VI.

Lathropus sepicola (Müller P. W. J., 1821)

BNP: [107A] 1 ex. 22.VI.-8.VIII.

\section{Latridiidae}

Corticaria crenicollis Mannerheim, 1844

Hajnówka: [629D] 1 ex. (male), 18.V.-21.VI.

Remarks: New species for Poland. It has been recently recorded from the Białowieża Forest based on two specimens (male and female, ex cult. VI.2013) reared from rotting wood of aspen (Populus tremula L.) (unpublished data, see Hilszczański et al. 2014 for detailed characteristics of the habitat). The species is known from few European countries: the Czech Republic (Bohemia), Slovakia (Zahradník 2017), Bosnia and Herzegovina, Belarus, Russia (Central and North European Territory), Finland, Norway and Sweden as well as from Asia: Russia (east and west Siberia) (Johnson 2007).

The existing data on C. crenicollis habitats are not conclusive. Some of literature data refer to the association of this species with dead wood and wood-decaying fungi living under the bark of aspen, birch (Betula spp.) and oak (Quercus spp.) (e.g. Rücker 1992). However, other studies suggest the relationship between $C$. crenicollis and ants, namely Formica rufa Linneaus (Päivinen et al. 2002). On the other hand, earlier records indicate the connection of this species with synanthropic environments, i.e. old wine cellars (Strzelczyk \& Stegner 1992). The present study indicates that $C$. crenicollis is also a forest species.
Corticaria foveola (Beck, 1817)

Browsk: [747C] 1 ex. (male), 23.VI.-8.VIII.

Remarks: The species was recorded in Poland (from Masurian Lake District) more than 80 years ago (see Horion 1961 and the references cited therein).

\section{Leiodidae}

Sciodrepoides alpestris Jeannel, 1934

Hajnówka: [627B] 1 ex. 21.VI.-4.VIII.

\section{Lycidae}

Benibotarus taygetanus (Pic, 1905)

BNP: [225B] 1 ex. 22.VI.-8.VIII., [197A] 1 ex. 25.VI.-9.VIII.

Hajnówka: [443B] 1 ex. 25.VI.-9.VIII.

Remarks: So far, the species has been known only from four regions of Poland, i.e. the Masurian Lake District, the Upper Silesia, the Eastern and the Western Beskidy Mountains, and the Bieszczady Mountains (Burakowski et al. 1985, Szafraniec et al. 1999, Szczepański et al. 2015, Plewa \& Borowski 2016, Twardy 2016).

\section{Melandryidae}

Anisoxya fuscula (Illiger, 1798)

Białowieża: [446A] 1 ex. 20.V.-22.VI.

Browsk: [155A] 1 ex. 20.VI.-5.VIII

Osphya bipunctata (Fabricius, 1775)

Białowieża: [671C] 10 exx. 18.V.-20.VI.

Browsk: [754B] 2 exx. 17.V.-23.VI.

Hajnówka: [487D] 1 ex. 18.V.-22.VI., [489A] 2 exx. 18.V.-22.VI., [601C] 1 ex. 18.V.20.VI.

Remarks: A rare species, known only from few localities, mainly in Western and Southern Poland (Kubisz et al. 2014).

The results of recent studies carried out in the oak stands indicate its preferences for treetops (Plewa et al. 2011, 2014, 2017).

\section{Mycetophagidae}

Litargus balteatus LeConte, 1856

Hajnówka: [575D] 1 ex. 17.V.-22.VI.

Remarks: Sub-cosmopolitan expansive species known in Poland since 1991 (Burakowski et al. 2000). 


\section{Ptinidae}

Hemicoelus fulvicornis (Sturm J., 1837)

Białowieża: [403D] 1 ex. 19.VI.-4.VIII.

Ptinus pilosus Müller P. W. J., 1821

Browsk: [40A] 1 ex. 19.VI.-3.VIII., [155A] 1 ex. 24.V.-20.VI., [155A] 1 ex. 20.VI.-5.VIII.

\section{Ripiphoridae}

Pelecotoma fennica (Paykull, 1799)

Browsk: [82C] 1 ex. 19.VI.-4.VIII.

\section{Salpingidae}

Rabocerus gabrieli (Gerhardt, 1901)

BPN: [287B] 1 ex. 22.V.-19.VI.

\section{Staphylinidae}

Acrotona parens (Mulsant et Rey, 1852)

Browsk: [743A] 1 ex. 23.VI.-8.VIII.

Hajnówka: [331C] 1 ex. 24.VI.-9.VIII., [359A] 1 ex. 25.V.-24.VI.

Amischa (Amischa) filum (Mulsant et Rey, 1870)

Browsk: [156D] 1 ex. 6.VIII.-9.IX.

Remarks: Third country record. The species was recorded as new for Poland from Zawoja, southern Poland (Melke \& Szafraniec 2003) and recently also from the Karkonosze Mountains (Mazur et al. 2016).

Atheta (Mocyta) amplicollis (Mulsant et Rey, 1874)

Hajnówka: [247A] 1 ex. 25.VI.-8.VIII., [275D] 1 ex. 25.VI.-8.VIII., [385C] 1 ex. 24.VI.7.VIII., [575D] 1 ex. 22.VI.-6.VIII.

Remarks: Second country record. Previously the species has been recorded from WrocławWojnów (Borowiec 1990).

Atheta (Microdota) boreella Brundin, 1948

BNP: [258B] 1 ex. 22.VI.-7.VIII.

Browsk: [156D] 1 ex. 20.VI.-6.VIII.

Remarks: Fourth country record. Recently recorded from Babia Góra (Melke \& Szafraniec 2003).

Atheta (Badura) cauta (Erichson, 1837)

Hajnówka: [385C] 1 ex. 19.V.-24.VI.

Atheta (Mocyta) clientula (Erichson, 1839)

Browsk: [178A] 1 ex. 21.VI.-6.VIII., [769B] 1 ex. 23.VI.-8.VIII.
Remarks: The species is rarely collected. Recently recorded from Lower Silesia (Klukowski et al. 2010).

Atheta (Atheta) pfaundleri Benick G., 1940

BNP: [313B] 1 ex. 8.VIII.-15.IX.

Remarks: Second country record. Previously the species has been recorded from Poland from Borecka Forest (Melke \& Maciejewski 1999).

Calodera riparia Erichson, 1837

Hajnówka: [438A] 1 ex. 18.V.-24.VI.

Carpelimus (Trogophloeus) heidenreichi Benick L., 1934

Hajnówka: [359A] 1 ex. 24.VI.-9.VIII., [438A] 1 ex. 24.VI.-7.VIII.

Browsk: [149B] 1 ex. 21.VI.-6.VIII., [743A] 1 ex. 23.VI.-8.VIII.

Remarks: Third country record. Previously the species has been recorded from Lublin Upland (Staniec 2000) and Kampinos Forest (Marczak et al. 2013).

Carpelimus (Taenosoma) lindrothi (Palm, 1943)

Browsk: [52B] 1 ex. 23.V.-19.VI.

Carpelimus (Trogophloeus) subtilis (Erichson, 1839)

Hajnówka: [273C] 1 ex. 23.V.-25.VI., [331C] 1 ex. 25.V.-24.VI., [438A] 1 ex. 18.V.24.VI.

Dochmonota rudiventris (Eppelsheim, 1886)

Hajnówka: [438A] 1 ex. 18.V.-24.VI.

Białowieża: [606D] 1 ex. 19.V.-20.VI.

Browsk: [156D] 1 ex. 24.V.-20.VI.

Remarks: Third country record. Recently recorded in the vicinities of Skwierzyna (Renner \& Messutat 2007).

Enalodroma hepatica (Erichson, 1839)

Białowieża: [641B] 1 ex. 20.VI.-4.VIII.

Hajnówka: [666B] 1 ex. 20.VI.-3.VIII.

Euconnus (Cladoconnus) denticornis (Müller P. W. J. et Kunze, 1822)

Hajnówka: [517B] 1 ex. 18.V.-22.VI.

Browsk: [740C] 1 ex. 23.VI.-8.VIII.

Remarks: One of the few presently known localities in Poland. Recently the species was recorded in the vicinity of Poznań (Jałoszyński 2003). 
Euconnus (Euconnus) hirticollis (Illiger, 1798) Hajnówka: [542A] 1 ex. 17.V.-22.VI.

Eutheia scydmaenoides Stephens, 1830 Białowieża: [451B] 1 ex. 8.VIII.-15.IX. BNP: [283B] 1 ex. 20.V.-25.VI. Hajnówka: [442E] 1 ex. 22.VI.-7.VIII.

Euthiconus conicicollis (Fairmaire, 1855) BNP: [194B] 1 ex. 22.VI.-8.VIII.

Holobus flavicornis (Lacordaire, 1835) Hajnówka: [271A] 1 ex. 24.V.-25.VI.

Meotica filiformis (Motschulsky, 1860)

Hajnówka: [384A] 1 ex. 24.VI.-7.VIII., [438A] 2 exx. 18.V.-24.VI., [438A] 2 exx. 24.VI.-7.VIII., [464C] 1 ex. 18.V.-22.VI.

Białowieża: [451B] 1 ex. 25.VI.-8.VIII.

BNP: [162C] 1 ex. 24.V.-22.VI., [162C] 1 ex. 22.VI.-8.VIII., [258B] 1 ex. 24.V.-22.VI., [314D] 1 ex. 20.V.-25.VI.

Browsk: [5D] 1 ex. 25.V.-19.VI., [6B] 1 ex. 25.V.-19.VI., [95B] 1 ex. 23.V.-21.VI.

Remarks: The species was recorded as new for Poland about a decade ago (Renner \& Messutat 2007). Recently also found in Kampinos Forest (Marczak et al. 2012) and in the SpałaRogów forests complex (Mokrzycki et al. 2013).

Othius volans Sahlberg J. R., 1876

Browsk: [1B] 1 ex. 17.V.-19.VI.

Remarks: Third country record. Previously known only from Borecka Forest (Melke \& Maciejewski 1999) and from the Słowińskie Błota Reserve, by the Baltic Sea (Sławska \& Smoleński 2003).

Philonthus (Philonthus) jurgans Tottenham, 1937

Browsk: [127A] 1 ex. 24.V.-20.VI.

Remarks: Rarely encountered species. Recently recorded in the Gipsowa Góra Reserve, in Silesia (Melke \& Grzywocz 2002), and from the Częstochowska Upland (Kościelny 2005).

Phloeonomus sjobergi Strand, 1937

Browsk: [153D] 1 ex. 20.VI.--5.VIII., [178A] 1 ex. 21.VI.-6.VIII.

Quedius truncicola Fairmaire, 1856

Browsk: [79C] 1 ex. 22.VI.-4.VIII.
Reichenbachia juncorum (Leach, 1817)

Białowieża: [581C] 1 ex. 18.V.-20.VI.

Remarks: Rarely found, recently recorded from Świętokrzyskie Mountains (Byk 2007).

Scydmaenus hellwigii (Herbst, 1792)

BNP: [162C] 1 ex. 22.VI.-8.VIII., [225B] 1 ex. 22.VI.-8.VIII., [283B] 1 ex. 25.VI.-8.VIII., [319D] 1 ex. 22.V.-23.VI., [346C] 1 ex. 22.V.26.VI.

Browsk: [23B] 1 ex. 7.VIII.-13.IX., [48D] 1 ex. 19.VI.-4.VIII., [80B] 1 ex. 19.VI.-4.VIII., [182D] 1 ex. 21.VI.-6.VIII., [188C] 1 ex. 20.VI.5.VIII., [740C] 1 ex. 23.VI.-8.VIII.

Hajnówka: [333C] 1 ex. 22.V.-24.VI., [383A] 1 ex. 24.VI.-5.VIII., [464C] 1 ex. 22.VI.7.VIII., [597A] 1 ex. 19.V.-23.VI., [669B] 1 ex. 20.VI.-3.VIII., [627C] 1 ex. 21.VI.-4.VIII.

Thamiaraea hospita (Märkel, 1845)

BNP: [317C] 1 ex. 8.VIII.-9.IX.

Hajnówka: [391A] 1 ex. 25.VI.-9.VIII.

Tachinus (Tachinus) bipustulatus (Fabricius, 1793)

Hajnówka: [334A] 1 ex. 25.VI.-9.VIII.

BNP: [258B] 1 ex. 22.VI.-7.VIII.

Tachinus (Tachinus) marginatus (Fabricius, 1793)

BNP: [228A] 1 ex. 20.V.-23.VI.

Remarks: The species is currently very rarely encountered. Last records were published several decades ago (Trella 1929, Szujecki 1963).

Tinotus morion (Gravenhorst, 1802)

Browsk: [156D] 1 ex. 24.V.-20.VI.

\section{Tenebrionidae}

Pentaphyllus testaceus (Hellwig, 1792)

Białowieża: [252B] 1 ex. 25.V.-25.VI.

\section{Tetratomidae}

Tetratoma fungorum Fabricius, 1790

Hajnówka: [663C] 1 ex. 17.V.-21.VI.

\section{Throscidae}

Trixagus leseigneuri Muona, 2002

Browsk: [46A] 1 ex. 19.V.-21.VI.

Hajnówka: [384A] 3 exx. 7.VIII.-12.IX.

Remarks: Thus far, the species has been recorded in two regions of Poland: the Wielkopolsko-Kujawska Lowland (Renner \& Messutat 
2007, Przewoźny 2011) and Upper Silesia (Szołtys \& Grzywocz 2014).

The species was recently separated from the very similar T. carinifrons (Bonvouloir, 1859) (Muona 2002).

\section{Zopheridae}

Synchita separanda (Reitter, 1882)

Białowieża: [426A] 1 ex. 20.V.-25.VI.

Remarks: The species has been encountered very rarely, currently known from two regions of Poland: the Wielkopolsko-Kujawska Lowland and the Pomeranian Lake District (Kubisz et al. 2015).

\section{Discussion}

Our research revealed 69 Coleoptera species new for the fauna of the Polish part of Białowieża Forest, despite the fact that this area has been considered relatively well known in this respect (Gutowski \& Jaroszewicz 2001, 2004). To our best knowledge, only few other studies have recently provided data on so many new species for this area (e.g. Szujecki 2001, Greń et al. 2017). Considering the relatively most up-to-date list by Gutowski and Jaroszewicz (2004), with 3,138 Coleoptera species, later publications in which new species were recorded (e.g. Greń et al. 2017), unpublished materials (K. Sućko, pers. comm.), as well as our results, the total number of known beetle species of the Białowieża Forest is approximately 3,250 .

The large number of new species in the present study can be explained by two main reasons. First, the intensive trapping effort with both the number of traps used and the duration of trapping. This holds for both, taxa with different habitat requirements and phenology, since traps were located in various areas of the Białowieża Forest and were exposed for almost the entire growing season of 2017. Second, the large number of species collected may be explained by the high effectiveness of the traps used in our study.

The multiple funnel trap was invented by Dr. Staffan Lindgren (hence the name Lindgren funnel trap) (Lindgren 1983). These traps are successfully used for surveying, monitoring and, to a lesser extent, control of bark- and wood-boring beetles, mainly scolytids, buprestids, and cerambycids. In recent years, a number of trap modifications were designed in order to optimize trapping of the target insects. These include the length of the trap (e.g. Miller \& Crowe 2010), trap color (Francese et al. 2010) and the use of various substances to increase the slipperiness of the trap surface and therefore enhance its efficacy (Francese et al. 2013). Taking into account the results of our research, as well as those of other authors, which show the high effectiveness of the trap type used here, these traps might be a very useful tool for studies focusing on various families of beetles.

Many of the captured beetles were caught in small numbers, which may reflect their rarity in the studied area. In fact, the list of the present study includes species, which are considered very rare or even absent in many areas. Particularly noteworthy are dead wood-dependent (saproxylic) species: Podeonius acuticornis, Isorhipis melasoides, Synchita separanda, Trixagus leseigneuri, Symbiotes gibberosus and Benibotarus taygetanus. Some other species, however, were captured relatively frequently, hence it is difficult to explain their absence in previous studies. The answer may be, again, the high efficiency of the traps used for trapping in the present study, and/or the increase of these species' abundances to the level, which allowed their detection.

In conclusion, the Białowieża Forest remains one of the most important areas regarding fauna of beetles. Using multiple funnel traps, as well as other trapping techniques, more new species could be detected in this area.

Acknowledgements. The authors would like to thank Wolfgang H. Rücker (Neuwied, Germany) for identification of Latridiidae. We also thank two anonymous reviewers who provided helpful comments on earlier drafts of the manuscript. The study was financed by the Polish State Forests, National Forest Holding under the project number 500443.

\section{References}

Borowiec, L. 1990: New records of Polish Staphylinidae (Coleoptera). - Polskie Pismo Entomologiczne 59: 817-820.

Borowiec, L., Kania, J. \& Wanat, M. 1992: Chrząszcze (Coleoptera) nowe dla Puszczy Białowieskiej. - Wiadomości Entomologiczne 11(3): 133-141. 
Borowski, J. \& Węgrzynowicz, P. 2012: The Powderpost Beetles of the World (Coleoptera: Bostrichidae). Vol. I. - Wyd. Mantis, Olsztyn, Poland. 461 pp. + XVI Plates.

Buchholz, L. 1987: The description of the larva and pupa of Podeonius acuticornis (Germar, 1824) (Coleoptera, Elateridae) with notes on its taxonomy, biology and geographical distribution. - Polskie Pismo Entomologiczne 56: 861-881.

Buchholz, L. 2004a: Podeonius acuticornis (Germar, 1824). - In: Głowaciński, Z. \& Nowacki, J. (eds.), Polish Red Book of Animals, Invertebrates: 118-119. Instytut Ochrony Przyrody PAN, Akademia Rolnicza im. Augusta Cieszkowskiego, Kraków - Poznań, Poland. $447 \mathrm{pp}$.

Buchholz, L. 2004b: Sericus subaeneus (G. Redtenbacher, 1842) - In: Głowaciński, Z. \& Nowacki, J. (eds.), Polish Red Book of Animals, Invertebrates: 121-122. Instytut Ochrony Przyrody PAN, Akademia Rolnicza im. Augusta Cieszkowskiego, Kraków - Poznań, Poland. $447 \mathrm{pp}$.

Buchholz L. 2008: Sprężyki (Coleoptera: Elateridae, Eucnemidae, Throscidae) rezerwatu leśno-stepowego "Bielinek nad Odrą" - charakterystyka i geneza fauny. — Wiadomości Entomologiczne 27(4): 195-258.

Burakowski B., 1962a: Biologia oraz opis larwy Ampedus elegantulus (Schönh.) (Coleoptera, Elateridae). Fragmenta Faunistica 10: 47-62. doi: https:// doi.org/10.3161/00159301FF1962.10.5.047

Burakowski, B. 1962b: Obserwacje biologiczno-morfologiczne na Pytho kolwensis Sahlb. (Coleoptera, Pythidae) w Polsce. - Fragmenta Faunistica 10: 173-204. doi: https://doi.org/10.3161/00159301FF1962.10.12.173

Burakowski, B. 1975: Descriptions of larva and pupa of Rhysodes sulcatus (F.) (Coleoptera, Rhysodidae) and notes on the bionomy of this species. - Annales Zoologici 32: 271-287.

Burakowski, B. 1988: Notes on the biology of Xylobanellus erythropterus (Baudi a Selve (Coleoptera, Lycidae), with description of the immature stages. - Polskie Pismo Entomologiczne 58: 575-585.

Burakowski, B. 1991: Cerophytidae, Eucnemidae, Throscidae, Lissomidae. Klucze do oznaczania owadów Polski, cz. XIX, zeszyt: 35-37. — Wrocław, Poland. $92 \mathrm{pp}$.

Burakowski, B. 2002: Description of the immature stages of Sericus subaeneus (W. Redtenbacher, 1842) (Coleoptera: Elateridae) with notes on biology and distribution. - Annales Zoologici 52(3): 367-372.

Burakowski, B., Mroczkowski, M. \& Stefańska, J. 1986: Dermestoidea, Bostrichoidea, Cleroidea i Lymexyloidea. Chrząszcze - Coleoptera. - Katalog fauny Polski 23(11): 1-243.

Byk, A. 2007: Waloryzacja lasów Gór Świętokrzyskich na podstawie struktury zgrupowań chrząszczy saproksylicznych. — In: Borowski, J. \& Mazur, S. (eds.), Waloryzacja ekosystemów leśnych Gór Świętokrzyskich metodą zooindykacyjną: 57-118. Wydawnictwo SGGW, Warszawa, Poland. 236 pp.
Francese, J. A., Rietz, M. L. \& Mastro V. C. 2013: Optimization of multifunnel traps for emerald ash borer (Coleoptera: Buprestidae): influence of size, trap coating, and color. - Journal of Economic Entomology 106(6): 2415-2423. doi: https://doi.org/10.1603/ EC13014

Francese, J. A., Crook, D. J., Fraser, I., Lance, D. R., Sawyer, A. J. \& Mastro V. C. 2010: Optimization of trap color for emerald ash borer (Coleoptera: Buprestidae). - Journal of Economic Entomology 103(4): 12351241. doi: https://doi.org/10.1603/EC10088

Greń, C., Lubecki, K. \& Przewoźny, M. 2017: Materiały do poznania chrząszczy wodnych (Coleoptera: Adephaga, Hydrophiloidea, Byrrhoidea, Myxophaga) Puszczy Białowieskiej. - Acta Entomologica Silesiana 25: $1-13$.

Gutowski, J. M. 2004: Bezkręgowce jako obiekt monitoringu biologicznego w Puszczy Białowieskiej. — Leśne Prace Badawcze 1: 23-54.

Gutowski, J. M. \& Jaroszewicz, B. (eds.) 2001: Katalog fauny Puszczy Białowieskiej. - Wyd. Instytut Badawczy Leśnictwa, Warszawa, Poland. 403 pp.

Gutowski, J. M. \& Jaroszewicz, B. 2004: Puszcza Białowieska jako ostoja europejskiej fauny owadów. - Wiadomości Entomologiczne 23(Suppl. 2): 67-87.

Gutowski, J. M. \& Kubisz, D. 1995: Entomofauna drzewostanów pohuraganowych w Puszczy Białowieskiej. - Prace Instytutu Badawczego Leśnictwa, Seria A 788: 91-129.

Hilszczański, J., Jaworski, T., Plewa, R. \& Ługowoj, J. 2014: Zavaljus brunneus (Gyllenhal, 1808) - a beetle species new to the Polish fauna (Coleoptera: Erotylidae). - Genus 25(3): 421-424.

Hilszczański, J., Plewa, R., Jaworski, T. \& Sierpiński, A. 2015: Microrhagus pyrenaeus Bonvouloir, 1872 - a false click beetle new for the fauna of Poland with faunistic and ecological data on Eucnemidae (Coleoptera, Elateroidea). — Spixiana 38(1): 77-84.

Horion, A. 1961: Faunistik der Mitteleuropäischen Käfer. Band VIII: Clavicornia 2. Teil (Thorictidae bis Cisidae), Teredilia, Coccinellidae. Überlingen-Bodensee, Germany. XVI + 375 pp.

Jałoszyński, P. 2003: Materiały do poznania Scydmaenidae (Coleoptera: Staphylinoidea) Niziny Wielkopolsko-Kujawskiej. - Wiadomości Entomologiczne 22(1): 13-24.

Jałoszyński, P. \& Konwerski, Sz. 2005: Nowe stanowiska chrząszczy z rodzaju Symbiotes L. Redtenbacher, 1849 (Coleoptera: Endomychidae) w zachodniej Polsce. - Wiadomości Entomologiczne 24(1): 49.

Johnson, C. 2007: Latridiidae. — In: Löbl, I. \& Smetana, A. (eds.), Catalogue of Palaearctic Coleoptera, Vol. 4: 635-648. Apollo Books, Stenstrup, Denmark. 935 pp.

Karpiński, J. J. 1933: Fauna korników puszczy Białowieskiej na tle występujących w puszczy typów drzewostanów. - Prace Instytutu Badawczego Lasów Państwowych, Seria A, Rozprawy i sprawozdania 1: 1-68.

Karpiński, J. J. 1949: Kózki (Cerambycidae) Puszczy Białowieskiej. — Prace Instytutu Badawczego Leśnictwa, Seria A, Rozprawy i Sprawozdania 55: 1-33. 
Klejdysz, T. \& Nawrot, J. 2010: First record of outdoor occurrence of stored-product Coleopterans in arable landscape in Poland. - Journal of Plant Protection Research 50(4): 551-553. doi: https://doi.org/ 10.2478/v10045-010-0091-4

Klukowski, Z., Irzykowicz, M. \& Mederski, P. 2010: Zróżnicowanie gatunkowe chrząszczy kusakowatych (Coleoptera: Staphylinidae) w uprawie rzepaku ozimego. - Zeszyty Naukowe Uniwersytetu Przyrodniczego we Wrocławiu, Rolnictwo 94(573): 41-54.

Kościelny, T. 2005: Badania nad kusakowatymi Wyżyny Krakowsko-Wieluńskiej (Coleoptera, Staphylinidae). Część II. - Biuletyn Częstochowskiego Koła Entomologicznego 3: 3-8.

Królik, R. 2002: Cis linearis J. Sahlberg, 1901 i Cis pseudolinearis Lohse, 1965 (Coleoptera: Ciidae) - nowe dla fauny Polski gatunki chrząszczy. - Wiadomości Entomologiczne 21(2): 97-101.

Królik, R. 2008: Ciidae (Coleoptera) w kolekcji Wojciecha Mączyńskiego. - Acta Entomologica Silesiana 16: $29-34$.

Kubisz, D. \& Szwałko, P. 1991: Nowe dla Podlasia i Puszczy Białowieskiej gatunki chrząszczy (Coleoptera). - Wiadomości Entomologiczne 10(1): 5-14.

Kubisz, D., Iwan, D. \& Tykarski, P. 2014: Tenebrionoidea: Tetratomidae, Melandryidae, Ripiphoridae, Prostomidae, Oedemeridae, Mycteridae, Pythidae, Aderidae, Scraptiidae. Critical checklist, distribution in Poland and meta-analysis. Coleoptera Poloniae 2. University of Warsaw, Faculty of Biology. Natura optima dux Foundation, Warszawa, Poland. 470 pp.

Kubisz, D., Iwan, D. \& Tykarski, P. 2015: Tenebrionoidea: Mycetophagidae, Ciidae, Mordellidae, Zopheridae, Meloidae, Pyrochroidae, Salpingidae, Anthicidae. Critical checklist, distribution in Poland and meta-analysis. Coleoptera Poloniae 3. - University of Warsaw, Faculty of Biology, Natura optima dux Foundation, Warszawa, Poland. 744 pp.

Lindgren, B. S. 1983: A multiple funnel trap for scolytid beetles (Coleoptera). - Canadian Entomologist 115(3): 299-302. doi: https://doi.org/10.4039/ Ent115299-3

Löbl, I. \& Smetana, A. (eds.) 2007: Catalogue of Palaearctic Coleoptera. Elateroidea, Derodontoidea, Bostrichoidea, Lymexyloidea, Cleroidea, Cucujoidea. Vol. 4. - Apollo Books, Stenstrup, Denmark. 935 pp. doi: https://doi.org/10.1163/9789004260894 004

Löbl, I. \& Smetana, A. (eds.) 2008: Catalogue of Palaearctic Coleoptera. Tenebrionoidea. Vol. 5. - Apollo Books, Stenstrup, Denmark. 670 pp. doi: https:// doi.org/10.1163/9789004260900_011

Löbl, I. \& Smetana, A. (eds.) 2011: Catalogue of Palaearctic Coleoptera. Curculionoidea I. Vol. 7. - Apollo Books, Stenstrup, Denmark. 373 pp.

Löbl, I. \& Löbl, D. (eds.) 2015: Catalogue of Palaearctic Coleoptera. Hydrophiloidea-Staphylinoidea. Vol. 2. Revised and Updated Edition. - Brill, Leiden, Boston. XXVI + 1702 pp. doi: https://doi.org/10.1163/ 9789004296855003

Marczak, D., Melke, A. \& Masiarz, J. 2013: Calodera cochlearis Assing, 1996 (Coleoptera: Staphylinidae)gatunek nowy dla Polski oraz inne gatunki rzadkich kusakowatych nowe dla Niziny Mazowieckiej. - Wiadomości Entomologiczne 32(3): 165-178.

Marczak, D., Hoste-Danyłow, A., Pepłowska-Marczak, D., Melke, A., Pacuk, B. \& Masiarz, J. 2012: Nowe stanowiska rzadkich, interesujących i chronionych gatunków chrząszczy (Coleoptera) w faunie Kampinoskiego Parku Narodowego. - Parki Narodowe i Rezerwaty Przyrody 31(1): 109-119.

Mazur, A., Klejdysz, T., Dobrowolski, M., Konwerski, S., Królik, R., Łabędzki, A., Mazur, M. A. \& Przewoźny, M. 2016: Chrząszcze saproksyliczne Karkonoszy. Część I - wykaz gatunków. - Acta Scientiarum Polonorum Silvarum Colendarum Ratio et Industria Lignaria 15(4): 269-295.

Melke, A. \& Maciejewski, K. H. 1999: Badania nad chrząszczami (Coleoptera) Puszczy Boreckiej. Część V. Kusakowate (Staphylinidae). — Wiadomości Entomologiczne 18(3): 143-151.

Melke, A. \& Grzywocz, J. 2002: Kusakowate (Coleoptera: Staphylinidae) odłowione w rezerwacie kserotermicznym „Gipsowa Góra” na Górnym Śląska. - Rocznik Naukowy PTOP "Salamandra" 6: 49-56.

Melke, A. \& Szafraniec, S. 2003(2002): Materiały do poznania Aleocharinae (Coleoptera: Staphylinidae) Beskidu Zachodniego. - Wiadomości Entomologiczne 21(4): 197-203.

Miller, D. R. \& Crowe, C. M. 2009: Length of multiplefunnel traps affects catches of some bark- and woodboring beetles in a slash pine stand in northern Florida. - Florida Entomologist 92(3): 506-507. doi: https://doi.org/10.1653/024.092.0315

Mokrzycki, T., Borowski, J., Byk, A. \& Rutkiewicz, A. 2013: Waloryzacja ekosystemów Leśnego Kompleksu Promocyjnego "Lasy Spalsko-Rogowskie" na podstawie struktury zgrupowań chrząszczy (Coleoptera) zasiedlających pniaki. - Studia i Materiały CEPL w Rogowie, R.15. 35(2): 48-81.

Muona, J. 2002: Trixagus leseigneuri n. sp. (Coleoptera, Throscidae). - Bulletin de la Société entomologique de France 107(2): 187-190.

Pawłowski, J., Kubisz, D. \& Mazur, M. 2002: Coleoptera Chrząszcze. - In: Głowaciński, Z. (ed.), Czerwona lista zwierząt ginących i zagrożonych w Polsce: 88110. Instytut Ochrony Przyrody PAN, Kraków, Poland. 155 pp.

Plewa, R. \& Królik, R. 2013: Potwierdzenie występowania w Polsce Orthocis linearis (J. R. Sahlberg, 1901) (Coleoptera: Ciidae). — Wiadomości Entomologiczne 32(3): 232-233

Plewa, R. \& Borowski, Z. 2016: Nowe stanowiska interesujących gatunków chrząszczy saproksylicznych (Coleoptera) w wybranych leśnych kompleksach promocyjnych w Polsce. - Wiadomości Entomologiczne 35(1): 5-13.

Plewa, R., Hilszczański, J. \& Jaworski, T. 2011: New records of some rare saproxylic beetles (Coleoptera) in Poland. - Opole Scientific Society Nature Journal 44: 120-131. 
Plewa, R., Jaworski, T. \& Hilszczański, J. 2014: Martwe drewno a jakościowa i ilościowa struktura chrząszczy (Coleoptera) saproksylicznych w drzewostanach dębowych. - Studia i Materiały CEPL w Rogowie, R.16. 41(4): 279-299.

Plewa, R., Jaworski, T., Hilszczański, J. \& Horák, J. 2017 : Investigating the biodiversity of the forest strata: The importance of vertical stratification to the activity and development of saproxylic beetles in managed temperate deciduous forests. - Forest Ecology and Management 402: 186-193. doi: https://doi.org/10.1016/ j.foreco.2017.07.052

Przewoźny, M. 2011: Rare and interesting beetles (Coleoptera) caught in the Sierakowski Landscape Park. Badania fizjograficzne, R. II, Seria C, Zoologia (C52): 33-45.

Przewoźny, M. 2013: Chrząszcze (Coleoptera) okolic Jeziora Maltańskiego w Poznaniu - supplement. - Wiadomości Entomologiczne 32(1): 34-41.

Renner, K. \& Messutat, J. 2007: Untersuchungen zur Käferfauna der Umgebung von Skwierzyna im westlichen Polen (Wielkopolska). - Coleo - Arbeiten und Berichte aus der Coleopterologie 8: 16-20.

Rücker, W. H. 1992: 58 Familie: Latridiidae. — In: Lohse, I. \& Lucht W. H. (eds.), Die Käfer Mitteleuropas, Band 13, 2. Supplementband: 139-160. Goecke \& Evers, Krefeld, Germany. 375 pp.

Sławska, M. \& Smoleński, M. 2003: Skoczogonki (Collembola) i kusakowate (Staphylinidae) torfowisk wysokich. - Wyd. SGGW, Warszawa, Poland. 95 pp.

Staniec, B. 2000: Carpelimus heidenreichi Benick, 1934 i C. similis (Smetana, 1967) chrząszcze nowe dla fauny Polski oraz występowanie innych gatunków z rodzaju Carpelimus Samouelle, 1819 (Coleoptera: Staphylinidae) w środkowo-wschodniej części kraju. - Wiadomości Entomologiczne 19(2): 79-84.

Strzelczyk, P. \& Stegner, J. 1992: Metophthalmus serripennis (Broun, 1914) (Coleoptera: Latridiidae) in Deutschland. - Entomologische Nachrichten und Berichte 36(2): 134-135.

Szafraniec, S., Szołtys H. \& Melke, A. 1999: Materiały do poznania chrząszczy (Coleoptera) saproksylicznych w wybranych projektowanych rezerwatach przyrody byłego województwa katowickiego. — Natura Silesiae Superioris 3: 77-86. Centrum Dziedzictwa Przyrody Górnego Śląska, Katowice, Poland.

Szczepański, W., Taszakowski, A., Karpiński, L. \& Tomecka, M. 2015: Materiały do znajomości omomiłkowatych, karmazynkowatych i świetlikowatych (Coleoptera: Elateroidea: Cantharidae, Lycidae, Lampyridae) Beskidu Wschodniego. - Acta Entomologica Silesiana 23: 1-7.

Szołtys, H. \& Grzywocz, J. 2014: Materiały do poznania entomofauny Polski - Coleoptera. - Acta Entomologica Silesiana 22: 1-18.

Szujecki, A. 1963: Materiały do poznania Staphylinidae (Coleoptera) Polski. II. - Fragmenta Faunistica 11: 31-39. doi: https://doi.org/10.3161/00159301FF 1963.11.3.031

Szujecki, A. (ed.) 2001: Próba szacunkowej waloryzacji lasów Puszczy Białowieskiej metodą zooindykacyjną. Wydawnictwo SGGW, Warszawa, Poland. 411 pp.

Szujecki, A. (ed.) 2006: Zooindication-based monitoring of anthropogenic transformations in Białowieża Primeval Forest. - Warsaw Agricultural University Press, Warsaw, Poland. 444 pp.

Szujecki, A. 2017: Kusakowate (Staphylinidae) lasów Polski. Aspekt różnorodności i monitoringu zooindykacyjnego. - Wyd. Dyrekcji Generalnej Lasów Państwowych - CILP, Warszawa, Poland. 47 pp.

Tarnawski, D., Suchan, T. \& Janoszek, M. 2007: Nowe stanowiska Ampedus suecicus (Palm, 1976) i Sericus subaeneus (Redtenbacher, 1842) (Coleoptera: Elateridae) w Górach Stołowych. - Przyroda Sudetów 10: 133-134.

Trella, T. 1929: Chrząszcze Przemyśla i okolicy. Staphylinidae, Pselaphidae, Clavigeridae. - Polskie Pismo Entomologiczne 8(1-4): 75-88.

Twardy, D. 2016: Nowe stanowiska Benibotarus taygetanus (Pic, 1905) i Erotides cosnardi (Chevrolat, 1831) (Coleoptera: Lycidae) w Polsce. — Wiadomości Entomologiczne 35(3): 186-187.

Zahradník, P. 2017: Check-list of beetles (Coleoptera) of the Czech Republic and Slovakia. - Nakladatelství Lesnická prace, s.r.o. 544 pp. 